\title{
Obstacles and Way Forward in Promoting Renewable Energy in Nigeria
}

\author{
Isaac N. Itodo*
}

\begin{abstract}
Department of Agricultural and Environmental Engineering, University of Agriculture, P. M. B. 2373, Makurdi, Nigeria
\end{abstract}

\begin{abstract}
Nigeria is one of the world's leading producers of crude oil and yet it is a net importer of refined oil. Its average daily premium motor spirit (PMS) consumption is 30 million liters. At 100\% capacity the nation's refineries will produce 17.74 million liters of premium motor spirit daily. A shortfall of over 10 million liters per day exists. Recent estimates stipulate that Nigeria requires 20,000 MW of electricity per annum. The projected electricity supply from all sources (conventional and renewable) in Nigeria in the short (2007), medium (2015) and long term (2025) is estimated to be $7000 \mathrm{MW}, 14000 \mathrm{MW}$ and 29,000 MW respectively. Annual peak electricity demand in Nigeria will increase from 4,558 MW to $45,755 \mathrm{MW}$ in 2050 at high growth rate and 4,558 to 19,599 MW for low growth. Nigeria's electricity per capita of $27 \mathrm{~W} /$ person is not enough to light an electric incandescent bulb of $30 \mathrm{~W}$. These provide enough justification for the use of renewable energy in Nigeria. The use of renewable energy in Nigeria is hindered by the lack of regulation, financial incentives, energy infrastructures, framework for sustainability and technical expertise. Overcoming these obstacles will require invigorating research and development in renewable energy technologies, training and education to build local technical capacity, diversification of energy mix and scaling up of renewable energy utilization, aggressive capacity building in all areas of energy development and creation of enabling environment that will attract investment in energy infrastructure. This paper discusses the obstacles and way forward in promoting renewable energy in Nigeria.
\end{abstract}

Keywords: Obstacle, way forward, promotion, renewable energy, Nigeria.

\section{INTRODUCTION}

\subsection{Nigeria's Renewable Energy Outlook}

Nigeria is located in sub-Saharan Africa. Nigeria is endowed with energy resources such as crude oil, natural gas, coal, hydropower, solar, wind, geothermal, biomass, tidal and wave energy which are unevenly distributed (Table 1) [1]. It has crude oil and gas in its Delta region, wind in the coastal South and the highlands of the central North East and far north, solar irradiance in all locations, particularly the far northern states. Despite its huge energy resources access, availability and affordability of energy is relatively very low.

There is energy poverty as in many African countries and overdependence on biomass. Biomass currently accounts for $97 \%$ of household energy needs of Nigerians for cooking and heating [1]. Nigeria has a total of about $1 \mathrm{MW}$ dispersed solar PV installations [2]. The benefits of renewable energy (RE) include improvement in rural infrastructure, employment generation, technology transfer, international collaboration and improved energy security resulting from decentralized energy generation. These will result in improved rural livelihood by the stimulation of cottage industries in the rural areas.

*Address correspondence to this author at the Department of Agricultural and Environmental Engineering, University of Agriculture, P. M. B. 2373, Makurdi, Nigeria; Tel: +23 4805462 1424; E-mail: dritodo@yahoo.com
Table 1: Renewable Resources of Nigeria

\begin{tabular}{|c|c|}
\hline Energy Source & Capacity \\
\hline \hline Hydropower, large & $10,000 \mathrm{MW}$ \\
\hline $\begin{array}{c}\text { Hydropower, small } \\
\text { scale }\end{array}$ & $734 \mathrm{MW}$ \\
\hline Fuelwood & $\begin{array}{c}13,071,464 \text { hectares } \\
\text { (Forest land as at 1981) }\end{array}$ \\
\hline Animal waste & 61 million tonnes/year \\
\hline Crop residue & 83 million tonnes/year \\
\hline Solar radiation & $3.5-7.0 \mathrm{kWh} / \mathrm{m}^{2}$-day \\
\hline Wind & $2-4 \mathrm{~m} / \mathrm{s}($ annual average) \\
\hline
\end{tabular}

Source: [1].

The justification for the use of RE is the narrowing gap between worldwide production of crude oil and its consumption. At current production, Nigeria's reserve will be depleted in forty years [3]. The objective of this paper is to provide an overview of the obstacles and way forward in deploying renewable energy technologies (RET) in Nigeria.

The world renewable energy outlook for 2011 (Table 2) [4] showed that additional RE capacity totaled $117 \mathrm{GW}$, which has raised the global cumulative installed capacity to $1460 \mathrm{GW}$ and annual power generation output to $427-4,761$ TWh. RE accounted for $17.5 \%$ of the global electricity market. Globally hydropower had the highest cumulative capacity - 
Table 2: Worldwide Installed Power Capacity of RET for Grid Connected Power Generation and Estimated Annual Energy Generation in 2011

\begin{tabular}{|c|c|c|}
\hline Renewable Energy Type & Cumulated Installed Capacity 2011 (GW) & Estimated Electricity Generation in 2011 (TWh/y) \\
\hline \hline Hydropower & $1,072.1$ & $3,353.1$ \\
\hline Wind power & 241.0 & 498.0 \\
\hline Solar PV & 65.6 & 76.6 \\
\hline Solar CSP & 1.7 & 3.2 \\
\hline Biomass power & 68.0 & $673.0-477.0$ \\
\hline Geothermal power & 11.3 & 1.2 \\
\hline Ocean and tidal energy & $<0.6$ & $4,272.3-4,476.3$ \\
\hline World total & $1,460.3$ & \\
\hline
\end{tabular}

Source: [4].

accounting for $73 \%$ of the total installed renewable capacity and $76 \%$ of the electricity generated from RE. Of the RE types, hydropower has the highest absolute growth of 73 TWh over $2011-2017$ [5].

New installations of wind turbines added $42 \mathrm{GW}$ to its overall total increasing its cumulative by $22 \%$ to 241 GW, which was the highest for all the RE types. The global market for small and medium wind turbine (SMWT) is forecasted to double between 2010 and 2015 especially in developing and emerging markets reaching USD 634 million [6]. These technologies have been successful in rural electrification projects. For example, China has over 400,000 SMWT systems.

In 2012 PV industry shipments to the first point of sale increased by $8 \%$ with a total power from the industries put at 25,473.0 MWp and revenue of $\$ 20,835.6$ [7]. The $2012-2013$ solar PV market review [8] showed an increase of $4 \%$ shipment growth to 23.5 GWp. The report showed a surge in Asia PV market. In 2011, Japan had an $11-12 \%$ share of the global PV shipment while China manufacturers had a $46-50 \%$ share of global shipment in 2012. Table 3 shows the rise in demand for solar PV between 2011 and 2013.
The demand for solar PV increased from 22,029.9 GWp in 2011 to $28,829.3 \mathrm{GWp}$ in 2013 [9].

The use of biomass technologies is spreading. The total capacity of biomass was $68 \mathrm{GW}$ at the end of 2011 [4]. China has emerged as a major global player in RE. China is expected to account for $40 \%$ of the 710 GW of new global RE capacity [5]. It is estimated that 1.6 million people all over the world are energy starved and lack access to energy, which is an obstacle to their development. 2.6 million People rely on wood, straw, charcoal and dung for cooking [10]. There is energy poverty in Africa even though Africa contributes $7 \%$ of the world's commercial energy and consumes 3\% [11].

\section{OBSTACLES TO THE DEPLOYMENT OF RENEWABLE ENERGY IN NIGERIA}

There are five policy mechanisms for accelerating $R E$ resources in developing countries like Nigeria [12]. These are regulations governing markets, electric grid access and quotas mandating capacity/generation, financial intervention and incentives, industry standards, education and information dissemination and public ownership and stakeholder involvement.

Table 3: Scenario for Continued Accelerated Growth in the PV Industry-Accelerated Regional Forecast 2011 - 2013

\begin{tabular}{|c|c|c|c|}
\hline Accelerated Demand Scenario & $\mathbf{2 0 1 1}$ & $\mathbf{2 0 1 2}$ \\
\hline \hline North America & $2,789.0$ & $4,795.8$ & $7,140.0$ \\
\hline Europe & $15,477.0$ & $14,509.2$ & $12,794.2$ \\
\hline Japan/China/India & $2,761.2$ & $4,796.2$ & $7,537.8$ \\
\hline Rest of the world & 1001.8 & 978.6 & $1,351.2$ \\
\hline Total Demand & $22,029.9$ & $25,079.8$ & $28,823.3$ \\
\hline
\end{tabular}

Source: [9]. 
The obstacles against the deployment of RE in Nigeria, will negate these identified mechanisms.

\subsection{Policies and Strategies}

Policies are drivers for promoting RE. The Nigerian government has no policies for promoting the deployment of RE. A healthy and implementable RE policy will jump start the participation of the private sector as major players in the deployment of RE in the country. The only RE policy in Nigeria is the Nigeria Biofuel Policy and Incentives approved by the Nigeria Federal Executive Council in 2007 which was gazetted in the Federal Republic of Nigeria gazette No. 72, Vol. 94 of $20^{\text {th }}$ June, 2007 [13]. The policy waived tax for business dealing with biofuels. The policy had zero tax for the biofuel industry in a tax holiday for the first 10 years of all registered businesses engaged in biofuel feedstock production, processing and marketing. The policy provided for the establishment of $\$ 62$ million fund as loans to investments in biofuels. The implementation of this policy has been zero because the implementation of the policy is domiciled in the Department of Petroleum Resources. The domiciliation of this policy in the Ministry of Petroleum Resources, a unit of Government that perceives biofuel as a rival commodity to petroleum has stalled the implementation of a very good policy. The policy should have been domiciled in the Energy Commission of Nigeria (ECN), a parastatal of government saddled with the responsibility of promoting the deployment of RE in Nigeria. The availability and implementation of a policy must go together to get the desired result. Policies are also required for solar $\mathrm{PV}$, wind and other $\mathrm{RE}$ resources.

\subsection{Lack of Technical Expertise and Standards}

The lack of technical expertise and standards has resulted in the failure of poorly designed and installed RE technologies across Nigeria. The commonest examples are the failed solar-powered street lighting projects that have reduced public confidence in RET. Government has also become wary of RE projects because of the failure of installed systems that millions of Dollars have been spent on.

Low public and government confidence in RET is a major factor militating against the promotion of RE in Nigeria. The availability of standards that take into cognizance local factors would have resulted in better designs and installations.

\subsection{Near Absence of Renewable Energy Education}

The curriculum of elementary, secondary and tertiary education in Nigeria has no subjects or courses on RE. RE is still largely unknown and unappreciated. However, there is RE education at postgraduate studies in some Nigerian universities, where they are offered in the Departments of Agricultural Engineering, Mechanical Engineering, Electrical/Electronic Engineering, Environmental Engineering and Physics. The ECN has established seven centers of RE in seven Nigerian universities for purposes of creating awareness in RE, undertake research in RE and support the universities in RE development. These are located in some universities in Nigeria such as: Usmanu Danfodio University, Sokoto, University of Nigeria, Nsukka, University of Benin, Benin, University of Ilorin, Ilorin, Abubakar Tafawa Balewa University, Bauchi, Obafemi Awolowo University, Ife and University of Lagos, Lagos. These energy centre's have not had the desired impact on RE education.

\subsection{Lack of Financial Incentives}

RET are expensive and their deployment is capitalintensive requiring huge investment costs. In Nigeria, there is no bank policy encouraging or devoting certain percentage of their lending portfolio to the promotion of green energy. For example, agriculture enjoys fiscal regulations that make money available to investors; there was once an agricultural development bank until their roles were taken over as agricultural departments in the commercial banks. The Bank of Industry, Nigeria that provides loans to the RE sector is more committed to the manufacturing sector. Financial incentives are required to support investment in $\mathrm{RE}$. The absence of this has put RE out of the reach of the common Nigerian.

\subsection{Public Ownership and Stakeholder Involvement in RE}

The lack of public liability RE industries/companies contributing to electricity generation is one of the factors limiting growth of the industry in Nigeria. There are public liability companies for conventional-source electricity generating plants in Nigeria. RE is generally considered a government matter. Public sector participation is in the form of small-scale solar PV businesses as vendors of PV gadgets and very few companies as government contractors. Despite the huge business advantage in RE investments, there is 
no Nigerian company involved in the generation of REsourced electricity that is adding to the grid electricity.

The knowledge and involvement of the public in $\mathrm{RE}$ is still very low in Nigeria compared to countries like the USA, Germany, United Kingdom, Israel, United Arab Emirate and South Africa. Farmers, health workers, industrialists, students and artisans who should be the main stakeholders in the sustainability and deployment of RET are often not involved in RE workshops. This has create a gap between the protagonists, harbingers and users of RET in the country.

\section{THE WAY FORWARD}

Energy is a serious issue. The shortfall of about $20,000 \mathrm{MW}$ of electrical demand in Nigeria can only be overcome by decentralizing the power sources and encouraging independent power generation feeding the national grid using RE sources such as wind farms, solar PV and biofuels. Implementable policies devoid of bureaucratic bottlenecks will be required to provide a conducive environment for RE in Nigeria. A law is required to empower the Energy Commission of Nigeria (ECN) to regulate RE practices in Nigeria. The creation of a Department of Standards, which should be responsible for the training and certification of $R E$ artisans and engineers. This is because standards are used to determine the correctness of designed and installed RETs. RE education, training and establishment of standards must be stepped up for Nigeria to meet her energy needs. RE policies should compel banks to commit a reasonable percentage of their loan portfolio to RE so as to increase investment in this sector. Furthermore, Federal Government/Central Bank of Nigeria policy on lending to RE, tax and import waivers for RE gadget is imperative for growth of the sector.

RE-related societies such as the Solar Energy Society of Nigeria (SESN) should shift from their traditional to creative methods of disseminating RETs. Solar clubs should be organized in primary and secondary schools. Annual solar carnivals/exhibitions in the major cities of the country will create awareness and support the growth of RET. The appointment of well-placed Nigerians as Solar Advocates will also promote the use of RETs. Establishing solar NonGovernmental Organizations (NGO) for village initiatives will guarantee the abundant use of RETs everywhere. Farmers, artisans, health workers and students as stakeholders should be major participants at solar workshops and conferences. This will create greater awareness and eliminate quackery in the use and deployment of RETs in the country. Budgetary incentives to $100 \%$ 'green energy' government establishments will surely boost the deployment of RE in Nigeria.

\section{CONCLUSION}

The RE master plan for Nigeria developed by the ECN showed that Nigeria has a huge reserve of RE resources that have not yet been exploited because of lack of implementable policies, lack of technical expertise and standards, a near absence of RE education and lack of financial incentives. Overcoming these obstacles will improve Nigeria's energy per capita and improve the standard of living of her people.

\section{NOMENCLATURE}

$$
\begin{aligned}
& \mathrm{PV}=\text { Photovoltaic } \\
& \mathrm{RE}=\text { Renewable energy } \\
& \text { RET = Renewable energy technology }
\end{aligned}
$$

\section{REFERENCES}

[1] ECN. Renewable Energy Resources, Technology and Markets. In: Renewable Energy Master Plan, Abuja: Energy Commission of Nigeria 2005; p. 3-4

[2] Bala EJ. An overview of energy situation in Sub-Sahara Africa. Paper presented at the workshop on sustainable energy development in Sub-Sahara Africa, Chelsea Hotel, Abuja; $19^{\text {th }}-20^{\text {th }}$ May 2009

[3] IEA. World energy statistics, 2007. In: Opuene A. Nigerian National Petroleum Corporation automotive biofuels initiative. National workshop on creating awareness for the use of automotive biodiesel and bioethanol as fuel for vehicles in Nigeria. Sheraton Hotels and Towers, Abuja; $9^{\text {th }}$ December 2009.

[4] Wiese A, Kleineidam P, Schallenberg K, et al. Renewable power generation 2011. Lahmeyer International, Germany. Renewable Energy Focus 2012; 13: 31-3.

[5] IEA accuses world governments of 'collective failure'. http://www.renewableenergyfocus.com

[6] Wiemann M. Small wind in a developing world. Renewable Energy Focus 2013; 14: 20-1. http://dx.doi.org/10.1016/S1755-0084(13)70027-9

[7] Mints P. Time to raise module prices? Renewable Energy Focus 2013; 14: $12-5$. http://dx.doi.org/10.1016/S1755-0084(13)70025-5

[8] Mints P. 2012 - 2013 solar PV market review - up a down staircase? Renewable Energy Focus 2012; 13: 20-1. http://dx.doi.org/10.1016/S1755-0084(12)70129-1

[9] Mints P. Solar: beginning of the big squeeze? Renewable Energy Focus 2011; 12: 36-7. http://dx.doi.org/10.1016/S1755-0084(11)70094-1

[10] Renewables 2010 Global Status Report. http://www. ren21.net/globalstatusreport/REN21_GSR_full.pdf

[11] British Petroleum Statistics. In: Itodo IN. Energy generation from agricultural wastes as alternative for powering SMEs. Paper presented at the Raw Materials Research and 
Development Council Techno-Expo 2011. Raw Materials Research and Development Council Auditorium, Abuja; $15^{\text {th }}$ $-18^{\text {th }}$ February 2011.

[12] Holm D. Renewable energy future for the developing world. International Solar Energy Society White Paper. Germany: Freiburg 2005.
[13]

Bala EJ. Overview of the biofuel policy and incentives in Nigeria under review. Paper presented at the national workshop on biodiesel for jatropha curcas: Role of biofue policy on sustainable energy development in Nigeria. Rockview Hotel, Abuja; $25^{\text {th }}-26^{\text {th }}$ September 2012. 